\title{
DIGITAL HERITAGE: ACADEMIC RESEARCH IN BRAZIL IN THE LAST FIVE YEARS
}

\author{
Ana Paula R. Araujo ${ }^{1 *}$, Claudio Antônio S. L. Carlos ${ }^{1}$, Julio Cesar R. Sampaio ${ }^{1}$, Ricardo Ferreira Vieira ${ }^{2}$ \\ ${ }^{1}$ UFRRJ, Dep. de Arquitetura e Urbanismo, Programa de Pós-graduação Patrimônio, Cultura e Sociedade, BR 465 km 7, Seropédica, \\ Rio de Janeiro/RJ, Brasil - (ana.r.araujo, claudio.limacarlos, julio.sampaio.ufrrj) @gmail.com \\ ${ }^{2}$ UFRRJ, Curso de Graduação em Arquitetura e Urbanismo, BR 465 km 7, Seropédica, Rio de Janeiro/RJ, Brasil -
} (rikrdim_pr@hotmail.com)

\section{Commission II, WG II/8}

KEY WORDS: Digital Heritage, Cultural Heritage Technologies, Education, Research, Keywords.

\begin{abstract}
:
In order to update and deepen the theoretical discussions about Digital Heritage, the authors initiated a survey of the most recent technologies that improves the documentation of architectural buildings and sites. We intend to implement a digital workflow on the studies of buildings and sites that have a potential of protection in the Fluminense lowland of Rio de Janeiro, Brazil. This is part of the activities of the conservation education at bachelor level in Architecture and Urbanism, and the course of the Postgraduate Program on heritage conservation of Universidade Federal Rural do Rio de Janeiro (UFRRJ). The main objective of the current scientific research is the identification of Brazilian researchers and the subjects that have been studied in the last five years in order to make a theoretical review through the systematization of topics, thematic axis, terms, concepts regarding the application of information and communication technologies (ICT) in the heritage documentation. We carried out a qualitative-quantitative mapping of the scientific production of twelve scientific events having occurred in Brazil and Latin America between 2013 and 2018. We detected 156 Brazilian researchers from all regions of the country that had researched about Digital heritage. The mapping of themes was compared to keywords index of CIPA-ICOMOS Symposium 2017 in order to identify points of contact and lack of studies in Brazil for planning the future research. The research group seek ways for better integration between national researchers, ways to get theoretical content up-to-date and to adopt more accurate documentation practices at undergraduate and postgraduate disciplines.
\end{abstract}

\section{INTRODUCTION}

Digital heritage comprises a wide variety of approaches and topics that involve researchers from multiple disciplines and are widely discussed by researchers of different countries. Digital technologies are increasingly important in research in the arts and humanities since they enhance digital workflow for documenting cultural heritage. We present the first part of the research - "The state of the art of the application of digital technologies in the documentation of material heritage in Brazil and abroad" that intends to systematize practices to build a workflow to be used in academic-scientific inventories considering ICTs in order to give greater efficiency to documentation heritage.

In order to identify ICTs applied to inventories of architectural heritage, we started with a theoretical review through the systematization of topics, thematic axis, terms, concepts regarding the application of information and communication technologies (ICT) in the heritage documentation. We aim to support the conservation teaching of the Undergraduate Course in Architecture and Urbanism and Postgraduate Program in Cultural Heritage of the Federal Rural University of Rio de Janeiro - UFRRJ.

\section{METHODOLOGICAL PROCEDURES}

At first, we searched for scientific articles that discuss digital heritage published in symposia, congresses, colloquiums, meetings to identify by keywords which topics are being studied. We systematized the main topics to: organizing the readings by thematic axes, monitoring the evolution of research in Brazil; constitute a definition of the terms in order to provide greater theoretical precision to the group of researchers; to seek a deeper theoretical understanding for Brazilian research and to establish new research themes. Secondly, the identification of Brazilian and foreign researchers has the following objectives: to monitor Brazilian and foreign scientific production according to key themes; identify potential partners for interinstitutional research; assist ICOMOS Brazil in structuring national scientific committees, in line with existing international standards.

We selected eleven scientific events in which there was a great participation of Brazilian educators and researchers in the cultural heritage discussion: Information and Communication Technology Meeting-TIC, 2015; Ibero-American Seminar of Architecture and Documentation-ArqDoc 2013 and 2015 and 2017; Scientific Symposium of the Ibero-American Society of Digital Graphics-SIGRADI, 2013 to 2018; ICOMOS Brazil Scientific Symposium, 2018. Then we organized by topics: DISCOVERY; SCIENTIFIC PROCESS and DISSEMINATION (Owen et al, 2004). For the comparison of Brazilian and foreign production, we have selected the scientific articles of the annals and archives of the International Symposium of the International Committee of Architectural Photogrammetry - CIPA-ICOMOS 2017 to identify if Brazilian research is up-to-date and if covers all international research topics.

TIC is a national event of the National Association of Built Environment Technology (ANTAC), dedicated to the application of Information and Communication Technology for the improvement of the design, production and management processes of buildings and cities. The VII Meeting of Information and Communication Technology, occurred in 2015, addressed

\footnotetext{
* Corresponding author
} 
the theme of Infrastructure and City Buildings: From BIM to CIM, and aimed at expanding the BIM concept to urban development scale, allowing us to glimpse a series of discussions about how Information and Communication Technologies can contribute to improve the quality of buildings and cities.

The $3^{\text {rd }}(2013), 4^{\text {th }}(2015)$ and $5^{\text {th }}$ (2017) Ibero-American Seminar of Architecture and Documentation - ArqDoc - held in Belo Horizonte $(\mathrm{MG})$ have made a great contribution to the research of architecture documentation presenting the Latin American Network of Architecture and Urbanism Collections - RELARQ. These seminars had the following themes about architecture and documentation: the challenges of new technologies; the research in the area of the history of Architecture and Urbanism; Constructive techniques and documentation.

XVII Congress of SIGraDi 2013, with the topic "Knowledgebased Design", proposed a reflection on ways of thinking and developing design in relation to information and digital resources. XVIII Congress of SIGraDi 2014 focused on "Design in Freedom" and sought to discuss the impact these two dimensions have on design and habitat disciplines - in their different scales and environments - in their technical, creative, cognitive, social, ethic? and educational aspects. XIX Congress of SIGraDi 2015 with the theme "Project information for interaction" promoted debates on the applications and possibilities of using digital graphics technologies. XX Congress of SIGraDi 2016, on the other hand, addressed the theme "Crowdthinking" that reveals how transdisciplinary thinking builds multiplicity and diversity in complex problems through collaborative work, distributed intelligences and collective research. XXI Congress of SIGraDi 2018 sought to discuss "Technopolitics" to broaden the debate on access and sharing of information, ways of executing, modes of participation, management, decision-making processes and production of cities, as well as the improvement of creative practices.

The II Scientific Symposium ICOMOS 2018 centred on the discussion about "The challenges of modern preservation" reserving a thematic axis for discussions on documentation, conservation and restoration heritage. Preserve architectural heritage is too important in our country, because we have numerous sites and historic buildings, that represents our culture.

The CIPA Scientific Symposium 2017, as a leader in the area of research on the use and innovations of digital technologies in the documentation for heritage conservation, had the theme "Digital Workflows for Heritage Conservation". The articles covered all stages of documentation (collecting, analysing, and dissemination of information) as well as the appropriate and innovative use of digital media in multidisciplinary research.

The keywords and the locality of the authors of 140 scientific articles about heritage documentation produced by 156 Brazilian researchers represent, on average, almost $8 \%$ of the scientific production of the selected scientific events:

- 04 articles $(6 \%)$ of 70 articles published in the Information and Communication Technology in Construction - TIC 2015;

- 73 articles (12\%) of 580 articles published in the IberoAmerican Architecture and Documentation Seminars- ArqDoc 2013, 2015 and 2017;

- 44 articles $(5 \%)$ of 795 articles published in the IberoAmerican Digital Graphic Congresses - SIGraDi 2013, 2014, 2015, 2016, 2017, 2018;

- 19 articles $(5 \%)$ of 354 articles presented at the II ICOMOS 2018 Scientific Symposium
At the CIPA Scientific Symposium held in Ottawa in 2017, all 164 scientific articles (annals and archives) produced by 436 researchers from 36 countries were selected for this study.

\section{EDUCATION AT ARCHITECTURE AND URBANISM UNDERGRADUATE AND HERITAGE, CULTURE AND SOCIETY POSTGRADUATE COURSE AT UFRRJ}

\subsection{The topics and practices in the conservation discipline}

The aim of the undergraduate course in architecture and urbanism is to train the student, through a review of the world evolution of conservation by theory readings of cultural heritage. Considering the development of the Heritage and Restoration of Constructed Heritage, the discipline (IT 819) proposes to the students designs of conservation interventions, considering updates in their architectural physical structures, and plans to consolidate urban areas. In order to do so, the students are taught to study the evolution of the main theoretical assumptions underlying the formation and development of conservation theory, with particular emphasis in the Brazilian context and its particularities manifested in the current legislation for the protection and conservation of architectural monuments and historical urban areas considering the technical bodies.

The theoretical module addresses the basic concepts of cultural heritage, the instruments of protection, history and conservation theory, the methodology of conservation projects and basic conservation techniques. In the practical module, the students elaborate projects of conservation of buildings and of urban areas. It generates documentation that identifies architectonic and urbanistic characteristics that make up their cultural identity in the Fluminense lowland. The municipality of Nova Iguaçu / RJ / Brazil has been studied since 2012. About 50 buildings were identified representing their urban and architectural memory. The vast majority without any kind of legal protection. The studies were developed by the students with proper guidance of the teachers responsible for the discipline.

In order to achieve these objectives, the course (60 hours per semester) is divided into two modules of two credits: one is dedicated to the conservation of urban areas and the other to the conservation of buildings. This programme is based on the experience of the similar discipline teaching plan of the Graduation Course of Architecture and Urbanism of the Federal University of Juiz de Fora from 2004 to 2010.

Regarding the module related to conservation buildings, the discipline develops ten themes related to the study and proposition of conservation interventions in previously selected cases. They are: introduction to conservation (instruments of protection and conceptual frame); historical research; analysis of the current conditions I (planimetry and altimetry); analysis of the current conditions II (remaining architectural features, ambience, current legislation, damage mapping, levels of deterioration and alterations); basic conservation techniques; and conservation proposals (preliminary and draft studies).

With respect to the module dedicated to urban conservation, a theoretical module is developed first, which addresses the main aspects that support the conservation of urban areas. Then, the students study a selected area of the universe of municipalities of Baixada Fluminense, currently in the municipality of Nova Iguaçu, as already mentioned. 
The analysis of the urban areas and buildings has the purpose of establishing protection areas of the built environment that are worked in the other module of the discipline. This study is concerned with the protection of the respective ambiences and the necessary improvements of their conditions of use. It may include proposals for protection of other built elements that may come to be identified as relevant to the local landscape composition. To this objective, the uses, the occupation, the height of the buildings and recurrent stylistic tendencies are mapped and evaluated. The result helps to identify incompatibilities, as well as to establish the limits of an environment area. It is proposed to the students to elaborate profiles and 3D models with the existing silhouettes according to the researched data.

\subsection{The topics of the postgraduate digital technology discipline}

The discipline "Digital technologies applied to the conservation of mobile and immovable assets" (IT 4011) of the "Heritage, Culture and Society Postgraduate Program" covers the inventory methodologies in Brazil, the technologies for data acquisition, documentation, visualization and interaction.

Concerning to inventories, we start with a historical perspective of inventories based on reference texts, patrimonial letters (Athens - 1931, Venice - 1964, UNESCO - 1972, Lausanne 1990, 1996, Letter of Burra - 1999, Ename - 2007, ICOMOS2008, London-2009, Seville-2010), and the Brazilian practices (Work Plan of Lucio Costa-1949, Historical Cities Program1970, National Inventory of Real Estate in Sites INBI-SU-19871979, Monumenta Program-2000-2010, PAC Historical Cities2007-2011). We focus on the means, techniques, technologies, principles and criteria for documentation of monuments, buildings and sites. It is important to identify what information and knowledge must be produced of different kinds of cultural heritage and whether there are guidelines for digital workflow.

On the subject of technologies for data acquisition, we use the systematization of technologies proposed by Owen et al (2004): DISCOVERY/INPUT stage that involves direct methods (Tactile, Hand measurement, Total station, EDM, GPS, levelling, Drawing) and indirect methods (Photogrammetry, Laser scanning, Remote sensing) in addition, the registration forms. For the organization of the programmatic content we also use as reference: principles for the recording (ICOMOS, 1996); metric survey techniques and information management tools, quality of data (accuracy, utility, verifiability) (Letellier, 2007); the phases of the conservation cycle (Diagnosis, Intervention, Monitoring, Evaluation); the classification of digital technologies (Direct and Indirect) (Santana-Quintero \& Addison, 2008); the CIPA/RecorDIM teaching manual (drawing, EDM, Rectified Photography, Photogrammetry, GPS, Laser scanning) and the differentiation of digital sensors (visual, Dimensional, Locational, Environmental) (Quintero, Blake, Eppich, 2007). We use the metric data acquisition technologies according to different levels of detail: low accuracy recognition; preliminary record with average accuracy, and detailed record with high accuracy.

The course covers the methodological sequence for the metric survey (photographic coverage, reading of texts and research of existing iconography, schematic drawings, measurement and annotation on materials, construction methods, state of conservation and final design). We emphasize the importance of the multispectral survey, in the complementation of the metric recording, to survey damages, anomalies, infestation, humidity, identification of internal materials to the constructive elements (identification of physical properties: irradiation, emissivity, reflection, wave and density).

We discuss about the characteristics of architectural design, since the graphic representation, that are translations and reductions of the real, and the capacity of influence directly on the quality of information and communication analysis. Concerning to the iconographic record, we highlight the importance of the photography record in Brazilian inventories of architectural heritage, as well as identify the guidelines and parameters to be adopted, procedures for image correction, manipulation and registration of the metadata.

Concerning the digital photogrammetry for recording, we present a historical perspective of the use of technology in the conservation of architectural heritage, its different types (spherical, panoramic, short distance, DSM, videogrametry), the integration with other technologies (Georeferencing, CAD, Geoprocessing, Laser scanner) and products produced from the processed data. We briefly present the point cloud processing, $3 \mathrm{~d}$ modelling and the existence of many applications (123DCatch, My3Dscanner, Meshlab, VisualSFM, OpenMVG, ArcGIS).

On the topic of technologies for documentation we classify them as SCIENTIFIC PROCESS (Owen et al, 2004): image processing, digital drawing, 3D modelling and Data/Information systems. About 3D modelling, we approach in the context of the digital heritage (UNESCO, 2003) (3D visualization, Digital library, Image processing, Field of interpretation) emphasizing the principles for interpretation of information and the importance of scientific transparency in documentation and interpretation (paradata) (Seville Charter, 2010). We present the steps of scientific method adopted for 3D modelling: information gathering, hypothesis formulation, predictions, experiments, data checking (Hermon in Bentkowska-Kafel et al, 2012).

We have included a brief presentation of the different CAD-BIMCIM, CAM, CAE systems as well as the parameterization processes of $3 \mathrm{~d}$ modelling. We highlight the 3D-IconsEUROPEANA project which proposes the digitization of a series of architectural and archaeological of cultural heritage and provides 3D models and digital content at Europeana. One of the objectives is to allow access to post-processing products (filling in holes, correcting corrupted duplicates, refinement and cleaning of image anomalies, texturing) of scans (444 posted models of 2941 3D scans) through EUROPEANA. We emphasize the possibility of structuring information through the metadata using the CARARE2 scheme. This plays an important role to ensure that the digital content of Europe's unique archaeological monuments, important buildings, historic city centers and worldclass industrial monuments are accessible from national libraries, archives, museums and other content providers.

Specifically, for the methodology of Building Information Modelling-BIM, Heritage Building Information ModellingHBIM (Murphy, 2007) and City Information Modelling-CIM, we approach the principles (parametrization, interoperability, precision and collaboration) applied to the process of conservation the architectural and urban sites heritage. These "tools" help to identify ambiguities and to define strategies of conservation. They could generate a source of reliable data for verification of interferences, conflicts, behaviour analysis (energy, structural) and building performance, as well as data sharing in integrated and collaborative work. The HBIM allows the integration of the acquired geometric data (TLS and/or Photogrammetry) in the digital models considering the 
constructive components and their parameters. It is possible to register the modifications during the life cycle of the construction, helping in the management (operation and maintenance - O\&M) of the cultural heritage.

We present the EPOCH Project (2004-2008) as a research reference. It brought together many European institutions to improve the quality and effectiveness of the use of information and communication technologies applied to cultural heritage. They tried to overcome the fragmentation of the research in the field. There were many challenges, such as the high cost of the technology (software and hardware) for processing the information, fragility of the equipment, the need for specialized training, lack of automation of procedures, difficulties in managing information from different resources and formats, lack of standardization of record data formats. The following tools were developed within the scope of the project: City Engine, Arc3D, Minidome, Imodelaser and UPGRADE, MeshLab, AMA and MAD, MobiComp and Cimad Application Broker, VHDPlus, Scene assembly Toolkit, Epoch Viewer.

In terms of information systems, we approach the documentation concepts (Pereira Filho, 2015), archival, audio-visual and iconographic documentation, documentation management, documents and its information (Architectural archival section SAR /International Council on Archives). We reinforce the importance of control systems, the use of metadata (CIDOCCRM), the thesauri, the quality criteria (reliability, accessibility, security). As an example, we present MIDAS HERITAGE (1998) developed by Forum of Information Standards in Heritage (FISH) that established guidelines to register information about historic sites in the United Kingdom. It provides a common basis for the development of information systems in the creation of historical records, in information sharing, data recovery and giving greater consistency to knowledge construction. Another example is the ARCHES (2010-2011) from the Getty Institute (GCI) and World Monuments Fund (WMF), an open source platform to store information on inventories of tangible and intangible cultural heritage. ARCHES make possible to register the heritage, register inventory, carry out research and analysis, monitoring of risks, help decision making by research of priorities and conservation actions. It uses Geographic Information System-GIS technology and the Core Data Standard for Archaeological and Architectural Heritage-CIDOC-CRM documentation methodology, approved by CIPA-ICOMOS. The last example is the Integrated Knowledge and Management System - SICG (2012), the first geographical intelligence to document cultural heritage developed by IPHAN (Brazil).

In the last thematic group of the discipline, DISSEMINATION/VISUALIZATION (Owen et al, 2004), we approached the digital media and its concepts, such as digital barrier, cyberspace, convergence, participatory culture, collective intelligence, hyper-reality, interactivity, interface, digital games, multimedia, security and surveillance, tracking, ubiquity, speed and virtuality. We include examples of virtual reality and augmented reality that can show the potential of interactions between users and information. We have identified several applications in the field of cultural heritage such as Architecture Walks, the NAI - Urban Augmented Reality, Augmented Reality Encyclopaedia (2006), the Archeoguide (Vlahakis, 2001). We also cover 3D printing technologies (Fused Deposition Modelling-FDM, Fused Filament Fabrication-FFF, Stereolithography-SLA, Digital Light Processing-DLP, Selective Laser Sintering-SLS, MultiJet, Colour Printing, Catalyst Resin, Die Casting and Microfusion, Plastic Injection Molding, CNC laser cutting / Milling / Router, Finishing and Post-Processing.
The survey in Latin America (Sperling, 2015) has revealed the use of digital fabrication in FabLabs to create historical building models, for example. Models printed by digital pathways can be useful as research tools for renovation and conservation studies, for documentation and source of information, for awareness and heritage education.

In order to improve the discipline, it is still necessary to update each topic considering national and foreign research, as well as the planning of implementing practical activities for the training of undergraduate and postgraduate students. In this sense, we set out to systematize the research through the identification of keywords, which facilitate the study of concepts, theories and practices.

\section{SURVEY OF TOPICS AND RESEARCHERS IN BRAZILIAN AND FOREIGN RESEARCH}

\subsection{Survey of the keywords as descriptors that synthesize the research}

The survey of keywords in scientific articles was carried out to facilitate the selection of articles by relevant topics to the ongoing research, and programmatic plans of undergraduate and postgraduate courses. "Keywords" is the smallest section of writing in scientific articles. It exposes the scope of a subject and the main concepts. In general, there is no pre-definition by the scientific committees of the events. Therefore, we can assume that authors can choose freely from the thematic axes of each meeting, symposium or scientific congress. Keywords are terms that have a direct link with the central themes of the investigation and serve to guide, give more selectivity and speed in the search for subjects, bringing a higher efficiency in the retrieval of information. Strategically, they should not be too generic, nor too specific, and should serve mainly for indexing in databases. Keywords can be simple or compound. It indicates that certain topics can be combined with others, or, when necessary, be more specific. Keywords are descriptors and their survey can form a thesaurus. An exhaustive collection of terms of determined knowledge that are arranged in alphabetical and semantical order.

A total of 373 keywords related to digital heritage topics were selected from the 304 Brazilian scientific articles and matched to the keywords published in the annals and archives of the CIPA 2017 Scientific Symposium. Due to the large number of keywords, we separated them into six large topic groups: DISCOVERY: 3d recording (71); SCIENTIFIC PROCESS: 3D imaging (33), 3D modelling (76), documentation (126); VISUALIZATION (56); PRINCIPLES (12). In the tables 1 to 6, gray texts were cited only by foreign researchers, and black texts only by Brazilian researchers.

We identified 34 keywords that occurred more frequently. In Table 1 we present the most cited keywords by more than ten researchers. The keywords highlighted in grey are those referred to by both foreign and Brazilian researchers:

\begin{tabular}{l|c|c}
\multicolumn{1}{c|}{ KEYWORDS (373) } & RESEARCH. & ARTICLES \\
\hline 3D RECORDING (71) & $\mathbf{9}$ & $\mathbf{2}$ \\
Photogrammetry & 94 & $\mathbf{4 0}$ \\
(3D) Laser scanning & 50 & $\mathbf{2 8}$ \\
Point cloud & 38 & 14 \\
Close range (Photogrammetry) & 26 & 8 \\
Digital workflow & 23 & 4 \\
Remote sensing & 20 & 4 \\
Terrestrial laser scanning & 19 & 5 \\
SFM (structure from motion) & 18 & 10
\end{tabular}




\begin{tabular}{l|c|c} 
Digitization & 15 & 7 \\
UAV (Unmanned Aerial & 14 & 4 \\
Vehicle) / VANT & 10 & 2 \\
Emergency recording & 17 & 3 \\
\hline IMAGING (33) & 11 & 4 \\
Mapping & 21 & 9 \\
\hline 3D MODELLING (76) & 42 & $\mathbf{3 4}$ \\
BIM & 34 & 15 \\
HBIM & 10 & 2 \\
Computer Aided Drawing & 11 & 2 \\
NURBS & 35 & 28 \\
\hline DOCUMENTATION (126) & 26 & 13 \\
GIS / SIG & 16 & 10 \\
Heritage Documentation & 16 & 2 \\
IT Documentation & 15 & 10 \\
Digital Documentation & 13 & 2 \\
Geomatics & 13 & 1 \\
CH Documentation & 12 & 2 \\
Decay (analysis) & 11 & 4 \\
Classification & 9 & 4 \\
\hline VISUALIZATION (56) & 10 & 9 \\
Augmented reality & 1 & 2 \\
\hline PRINCIPLES (12) & 10 & 3 \\
LOD (Level of Detail) & 10 & 2 \\
LOI (Level of Information) & 10 & 2 \\
\hline LOG (Level of Geometry) &
\end{tabular}

Table 1: Keywords with more frequency of appearance

In terms of 3D RECORDING technologies (table 2), Brazilians and foreigners have researched on Photogrammetry, $3 D$ laser scanning, Point cloud, Digitization and Unmanned Aerial Vehicle/VANT. However, we didn't find in Brazilian articles the keywords: Digital workflow, Handheld measurement, Remote sensing, Rapid documentation, Total station, Electronic Distance Measurement-EDM, and Distributed monitoring systems. The group of keywords about the topic 3D RECORDING was the one that involved the largest number of researchers (table 1)

\begin{tabular}{l|l|l|l}
\hline \multicolumn{1}{c|}{ MOST CITED } & \multicolumn{1}{|c|}{ By FOREING } & $\begin{array}{l}\text { By FOREING AND } \\
\text { BRAZILIAN }\end{array}$ & \multicolumn{1}{c}{$\begin{array}{c}\text { Only By } \\
\text { BRAZILIAN }\end{array}$} \\
\hline 3D, & Recording methods & & \\
3d recording & Autromated, & \\
\hline $\begin{array}{l}\text { Photogrammetry, } \\
\text { Close range }\end{array}$ & $\begin{array}{l}\text { Automated } \\
\text { Drone based }\end{array}$ & $\begin{array}{l}\text { Aerial Photogrammetry, } \\
\text { Close range }\end{array}$ & $\begin{array}{l}\text { Digital Photogram. } \\
\text { Spherical Photogram. }\end{array}$ \\
\hline $\begin{array}{l}\text { Laser scanning, } \\
\text { Terrestrial laser Scan }\end{array}$ & $\begin{array}{l}\text { Triangulation, } \\
\text { Structure light, } \\
\text { Laser scanner, } \\
\text { Simultaneous localization } \\
\text { and mapping, } \\
\text { Range based technique }\end{array}$ & $\begin{array}{l}\text { 3D scanning, } \\
\text { 3D Laser scanning }\end{array}$ & \\
\hline Digitization & $\begin{array}{l}\text { Digitization small objects, } \\
\text { Digitization world } \\
\text { heritage sites }\end{array}$ & $\begin{array}{l}\text { Digitalization of of } \\
\text { collections }\end{array}$ & $\begin{array}{l}\text { Scanning, } \\
\text { 3d digitization }\end{array}$ \\
\hline
\end{tabular}

Table 2: 3D RECORDING keywords

In the 3D IMAGING topic (table 3), we noticed that the keywords Mapping, Orthophoto and Image based technique are used both in Brazilians and foreign articles. The Dense Image Matching-DIM technique was used only by foreign researchers while similar terms like Dense Stereo Matching-DSM (DSP) and Dense Stereo Matching Tools were referred to only in Brazilian articles. We also verified the use of Panoramic Images and Spherical Panorama keywords by foreign surveys, and a similar keyword, Panoramic mosaic, by Brazilian surveys. Other terms identified were not referred to in Brazilian surveys such as: Image fusion, Near Infrared Images-NIR, Multispectral imaging, Texturing and Texture mapping.

\begin{tabular}{l|l|c|c}
\hline \multicolumn{1}{c|}{ MOST CITED } & \multicolumn{1}{|c|}{ By FOREING } & $\begin{array}{c}\text { By FOREING AND } \\
\text { BRAZILIAN }\end{array}$ & $\begin{array}{c}\text { By } \\
\text { BRAZILIAN }\end{array}$ \\
\hline 3D imaging & $\begin{array}{l}\text { Image techniques } \\
\text { Image Fusion } \\
\text { NIR Images } \\
\text { Multispectral (imaging) }\end{array}$ & Image based Technique & Image processing \\
\hline Mapping & $\begin{array}{l}\text { Condition Mapping } \\
\text { Digital survey mapping } \\
\text { technology, } \\
\text { Mobile mapping }\end{array}$ & - & - \\
\hline & $\begin{array}{l}\text { Map projection, } \\
\text { Normal map, } \\
\text { Decay (analysis) }\end{array}$ & - & - \\
\hline
\end{tabular}

\begin{tabular}{c|l|l|l}
\hline- & $\begin{array}{l}\text { Orthoimage, } \\
\text { Rectifying photograph }\end{array}$ & Orthophoto & $\begin{array}{l}\text { Ortho rectification } \\
\text { Rectification } \\
\text { images } \\
\text { Photo rectified }\end{array}$ \\
\hline- & $\begin{array}{l}\text { Texturing } \\
\text { Texturing mapping } \\
\text { Texure baking }\end{array}$ & - & - \\
\hline- & Dense image matching & - & $\begin{array}{l}\text { Dense stereo } \\
\text { matching, } \\
\text { Dense stereo } \\
\text { matching tools }\end{array}$ \\
\hline- & $\begin{array}{l}\text { Photographic lighting, } \\
\text { Photometric stereo }\end{array}$ & - & Photography \\
\hline- & $\begin{array}{l}\text { Panoramic images, } \\
\text { Spherical panorama }\end{array}$ & - & Panoramic mosaic \\
\hline- & - & - & Vectorization \\
\hline
\end{tabular}

Table 3: IMAGING keywords

In the group of terms related to 3D MODELLING (table 4), we found that Modelling, BIM and HBIM were most keywords referred to in both Brazilian and foreign articles. More generic terms like Model and $3 d$ Models are used by both Brazilian and foreign researchers. However, more specific terms like Mesh model and $3 D$ surface model were used only by Brazilians. More specific methods for modelling considering the information to be extracted such as Cloud to model, $3 D$ segmentation, Surface morphology, Semantic modelling, Semantic enrichment, Semantic technologies have not been identified in Brazilian research. Terms about modelling for interpretation such as Simulation, Algorithm, Parametric modelling, Parametric design, Numerical modelling and Program language were used by both Brazilians and foreigners. However, terms related to the modelling of larger spatial scales such as Cartography, CIM, City Geographic Markup language and Smart city were found only in Brazilian research. Terms related to modelling with traditional tools like Computer Aided Design-CAD, Computer graphics were used by Brazilian and foreign researchers, but similar terms such as Computer aided drawing, Computer aided drafting, CAD drawings were only identified in foreign research. Terms related to interaction and collaboration in a modelling process as Interactive model, Integrated digital model and Modelling and management information systems were only referred to by foreign researchers. Finally, 2D representation process as Drawing and Digital Drawing were identified in Brazilian research while Line drawing and Sketching in foreign research.

\begin{tabular}{|c|c|c|c|}
\hline MOST CITED & By FOREING & $\begin{array}{c}\text { By FOREING AND } \\
\text { BRAZILIAN } \\
\end{array}$ & $\begin{array}{c}\text { By } \\
\text { BRAZILIAN } \\
\end{array}$ \\
\hline $\begin{array}{l}\text { 3D modelling, } \\
\text { Modelling }\end{array}$ & $\begin{array}{l}\text { Building modelling, } \\
\text { Procedural modelling, } \\
\text { Typological modelling, } \\
\text { Solid modelling }\end{array}$ & Digital modelling & $\begin{array}{l}\text { Built heritage } \\
\text { modelling }\end{array}$ \\
\hline $\begin{array}{l}\text { Point cloud } \\
\end{array}$ & $\begin{array}{l}\text { Cloud to 3d model, } \\
\text { 3D segmentation }\end{array}$ & Segmentation & $\begin{array}{l}\text { TIN - Triangular } \\
\text { Irregular Network }\end{array}$ \\
\hline $\begin{array}{l}\text { HBIM, } \\
\text { BIM }\end{array}$ & $\begin{array}{l}\text { BHIMM, } \\
\text { Scan to BIM, } \\
\text { As-built BIM, } \\
\text { Revit Family Library }\end{array}$ & IFC & Autodesk Revit \\
\hline - & $\begin{array}{l}\text { Line drawing, } \\
\text { Sketching }\end{array}$ & - & $\begin{array}{l}\text { Drawing, } \\
\text { Digital drawing }\end{array}$ \\
\hline - & \begin{tabular}{l}
\multicolumn{2}{l}{ Structural analysis } \\
Structural dynamic \\
analysis, \\
FEM (Finite element \\
method), \\
FEA (Finite element \\
analysis)
\end{tabular} & $\begin{array}{l}\text { Simulation } \\
\text { Sin }\end{array}$ & Rendering \\
\hline - & $\begin{array}{l}\text { 3D parametric modelling, } \\
\text { Parametric model }\end{array}$ & $\begin{array}{l}\text { Parametric modelling, } \\
\text { Numerical modelling }\end{array}$ & $\begin{array}{l}\text { Algorithm, } \\
\text { Algorithmic } \\
\text { design, } \\
\text { Generative system, } \\
\text { Parametric design }\end{array}$ \\
\hline
\end{tabular}

Table 4: 3D MODELLING keywords

The group of terms related to DOCUMENTATION (table 5) is quite extensive, reflecting the variety of topics, techniques and technologies involved in the scientific processing of information. We emphasize that generic terms such as Digital documentation, Heritage documentation were the most cited by Brazilian and foreign research works. We have observed many variants (16) of the term Documentation which specify the object to be documented and procedures. Other recurrent terms such as Digital Heritage documentation, IT documentation, Database, Classification, Geomatics were referred to only in foreign articles. Different types of documents such as Digital document, 
Document resources and Photography were used only in Brazilian articles.

Many terms semantically related to Data have been identified as Data fusion, Historical data, Big data, Reusable Big data, Open data, Public data, Metadata, Data visualization. The keywords in relation to Database, found in Brazilian research, refer to different types of cultural heritage such as Architectural conservation database, Database of cultural objects, while other terms such as Heritage database and Inventory, Heritage databases, Heterogeneous database, Heritage registry refer more to procedures.

Many foreign articles have referred to Classification techniques terms such as Annotation, Ontology, Formal Ontology, Querying, Thesauri, Topics, SKOS, Defects keynote dictionary, Archiving, Digital archiving, Digital archive, Archival material and Image archives. Some terms found only in Brazilian research are related to the field of archivology such as Documentary organization, Semantic, Archive, Archivology, Archivology of architecture and urbanism.

With respect to Information management, we found terms such as Information systems and Information retrieval in Brazilian and foreign surveys. Types of information representation were also identified in Brazilian research works such as Architectural Information, Representation of Information, Graphic Representation, Cartographic Representation and only Historical maps in foreign research. We found established documentation references such as CIDOC-CRM, DOCUTOOLS, Arches (project), CHER-Ob and MOLAB only in foreign articles.

Finally, we detected terms related to Collections which most were identified in Brazilian research works such as Digital collection, Documentary collection, Iconographic collection, Collection management. Only two terms were cited by foreign articles such as Digitalization of collections and Digital preservation.

\begin{tabular}{|c|c|c|c|}
\hline MOST CITED & By FOREING & $\begin{array}{c}\text { By FOREING AND } \\
\text { BRAZILIAN }\end{array}$ & $\begin{array}{c}\text { By } \\
\text { BRAZILIAN } \\
\end{array}$ \\
\hline $\begin{array}{l}\text { Documentation, } \\
\text { Digital documentation, } \\
\text { Heritage } \\
\text { documentation } \\
\text { Cultural heritage } \\
\text { documentation, } \\
\text { IT documentation } \\
\end{array}$ & $\begin{array}{l}\text { 3D documentation, } \\
\text { Initial documentation, } \\
\text { Documentation } \\
\text { challenges, } \\
\text { Documentation } \\
\text { requirements }\end{array}$ & - & $\begin{array}{l}\text { Documentation } \\
\text { centre, } \\
\text { Photographic } \\
\text { documentation }\end{array}$ \\
\hline - & $\begin{array}{l}\text { Digital inventory, } \\
\text { Digital cultural heritage, } \\
\text { Digital record }\end{array}$ & - & $\begin{array}{l}\text { Digital heritage } \\
\text { Inventory, } \\
\text { Record } \\
\text { Architectural } \\
\text { digital record } \\
\end{array}$ \\
\hline - & $\begin{array}{l}\text { Data fusion, } \\
\text { Historical data } \\
\text { Big data, } \\
\text { Reusable big data, } \\
\text { Public data }\end{array}$ & Data & $\begin{array}{l}\text { Metadata, } \\
\text { Data visualization }\end{array}$ \\
\hline Database & $\begin{array}{l}\text { Heritage database and } \\
\text { inventory, } \\
\text { Heritage databases, } \\
\text { Heterogeneous dataset, } \\
\text { Heritage registry } \\
\end{array}$ & - & $\begin{array}{l}\text { Architectural } \\
\text { conservation } \\
\text { database, } \\
\text { Database of } \\
\text { cultural objects } \\
\end{array}$ \\
\hline Classification & $\begin{array}{l}\text { Annotation, } \\
\text { Ontology, } \\
\text { Formal ontology }\end{array}$ & 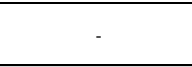 & $\begin{array}{l}\text { Documentary } \\
\text { organization }\end{array}$ \\
\hline- & $\begin{array}{l}\text { Multidisciplinary inf. } \\
\text { System } \\
\text { Information flow, } \\
\text { Information integration } \\
\text { Information settings } \\
\text { Heritage info. integration }\end{array}$ & $\begin{array}{l}\text { Information management } \\
\text { Information systems } \\
\text { Information retrieval }\end{array}$ & $\begin{array}{l}\text { Informational } \\
\text { practices }\end{array}$ \\
\hline
\end{tabular}

In the group of keywords related to VISUALIZATION (table 6) we observe terms related to interaction, dissemination and interpretation technologies. Compared to the other thematic groups, few terms were cited both by Brazilians and foreigners: Visualization, Virtual Reality, Augmented Reality, Virtual reconstruction, Virtual restoration and Animation. Generic terms such as $3 D$ visualization and Spatial visualization, Animation, Dissemination, Disseminating heritage information, Virtual Learning environments and GIS were identified only in foreign research and Advanced technologies of representation and visualization and Terrestrial heritage Atlas only in Brazilian research. Other comprehensive terms such as Artificial Intelligence, Cyberspace, Cybernetics, Robotics, Technology and Technology of Information and Communication have been identified only in Brazilian articles.

Technologies for direct communication such as Fabrication, 3D printing, Laser cutting, Scaled museum maquette were referred to in foreign research works, while similar terms such as Digital fabrication, FABLAB and Rapid prototyping only in Brazilian research. Terms related to device-mediated interaction prevailed such as, Virtual reality, Immersive, Immersive virtual reality, Sequential reality, Virtual tour, Virtual museum, Virtual recomposition, Virtual reconstruction, Virtual restoration and Virtual Simulation. Analogous terms such as Virtuality, Virtualization, Virtual Heritage and Human-Computer Interaction were found only in Brazilian surveys.

Tools used in heritage education such as Digital storytelling and Serious game were referred to in foreign research while Game, Videogame, Digital game, Engine game, Gamification appeared only in Brazilian articles. The Web environment technologies were identified in foreign research: Web application, Web services, Web sharing and New media and most of the terms in Brazilian: Website, Mobile apps, Mobile devices, Online platform, Platform, Digital media, Locative media, Hyperdocuments, Video documentary and QR code.

With regards to Geo Information we have identified a range of terms in both foreign (Geomatics, QGIS, Web GIS, Spatial Information, Google Earth) and Brazilian research ( $3 D$ GIS, ARC GIS, Geoprocessing, Geodesign, Referencing, Georeferencing, Geotechnology). GIS was the only keyword used by both.

Terms that relate to conditions of access and manipulation of information have been referred to mostly in foreign research (New technologies, Multimedia Documentation, Internet of things, Open source, Open access, Real time, Tablet based documentation Network design, Interactive Information Motion Design). Two programming languages were found in Brazilian research (HTML 5 and Java script).

\begin{tabular}{|c|c|c|c|}
\hline MOST CITED & By FOREING & $\begin{array}{c}\text { By FOREING AND } \\
\text { BRAZILIAN }\end{array}$ & $\begin{array}{c}\text { By } \\
\text { BRAZILIAN }\end{array}$ \\
\hline Visualization & $\begin{array}{l}\text { 3D visualization, } \\
\text { Spatial visualization }\end{array}$ & 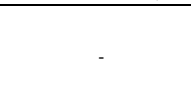 & $\begin{array}{l}\text { Adv. Tech. Of } \\
\text { representation and } \\
\text { visualization, } \\
\text { Territorial heritage } \\
\text { atlas }\end{array}$ \\
\hline - & $\begin{array}{l}\text { Digital Technologies, } \\
\text { Fabrication, } \\
\text { 3D Printing, } \\
\text { Laser cutting, } \\
\text { Scaled museum maquette }\end{array}$ & - & $\begin{array}{l}\text { Digital fabrication, } \\
\text { FABLAB, } \\
\text { Rapid prototyping }\end{array}$ \\
\hline - & $\begin{array}{l}\text { Immersive, } \\
\text { Immersive virtual reality, } \\
\text { Sequential reality }\end{array}$ & Virtual reality & $\begin{array}{l}\text { Virtuality, } \\
\text { Virtualization, } \\
\text { Human-computer } \\
\text { interaction }\end{array}$ \\
\hline Augmented reality & $\begin{array}{l}\text { Virtual tour, } \\
\text { Senate virtual tour, } \\
\text { Virtual museum } \\
\end{array}$ & - & 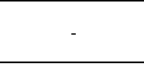 \\
\hline - & $\begin{array}{l}\text { Digital storytelling, } \\
\text { Serious games }\end{array}$ & Animation & $\begin{array}{l}\text { Game, } \\
\text { Videogame, } \\
\text { Digital game, } \\
\text { Engine game, } \\
\text { Gamification }\end{array}$ \\
\hline $\begin{array}{l}\text { Geomatics, } \\
\text { GIS }\end{array}$ & $\begin{array}{l}\text { QGIS, } \\
\text { WEBGIS, } \\
\text { Google earth }\end{array}$ & - & $\begin{array}{l}\text { ArcGIS, } \\
\text { 3D GIS }\end{array}$ \\
\hline - & $\begin{array}{l}\text { Virtual recomposition, } \\
\text { 3D reconstruction, } \\
\text { 3D/4D reconstruction, } \\
\text { 4D }\end{array}$ & $\begin{array}{l}\text { Virtual reconstruction, } \\
\text { Virtual restoration }\end{array}$ & $\begin{array}{l}\text { Virtual simulation, } \\
\text { Virtual heritage }\end{array}$ \\
\hline
\end{tabular}

Table 6: VISUALIZATION keywords 
The last group of keywords related to PRINCIPLES (table 7) include terms referring to quality criteria. We verified that there were a few words referred to by few researchers. All terms were used only in foreign articles (Accuracy, Level of accuracy-LOD, Geometric accuracy, Grade of accuracy, Precision, Level of detail-LOD, Mixed and reverse LOD, Level of information-LOI, Grade of information, Level of geometry-LOG e Grade of generation).

\begin{tabular}{c|l|c|c}
\hline MOST CITED & By FOREING & $\begin{array}{c}\text { By FOREING AND } \\
\text { BRAZILIAN }\end{array}$ & $\begin{array}{c}\text { By } \\
\text { BRAZILIAN }\end{array}$ \\
\hline- & $\begin{array}{l}\text { Principles, } \\
\text { Accuracy, } \\
\text { GOA (level of accuracy) } \\
\text { Geometric accuracy, } \\
\text { Grade of accuracy }\end{array}$ & - & - \\
\hline- & Precision & - & - \\
\hline LOD (Level of detail) & Mixed and reverse LOD & - & - \\
\hline $\begin{array}{l}\text { LOI (Level of } \\
\text { information) }\end{array}$ & $\begin{array}{l}\text { Grade of information, } \\
\text { Grade of generation }\end{array}$ & - & - \\
\hline $\begin{array}{l}\text { LOG (Level of } \\
\text { geometry) }\end{array}$ & - & - \\
\hline
\end{tabular}

Table 7: PRINCIPLES keywords diagram

\subsection{Survey of Brazilian and foreign researchers}

The intention is to identify a network of researchers. Five countries were identified aggregating the majority of foreign researchers: Italy (100), Canada (51), Belgium (20), Germany (19) and United Kingdom (15) (figure 7). However, there are thirteen countries that haven't interacted with other countries (figure 1)

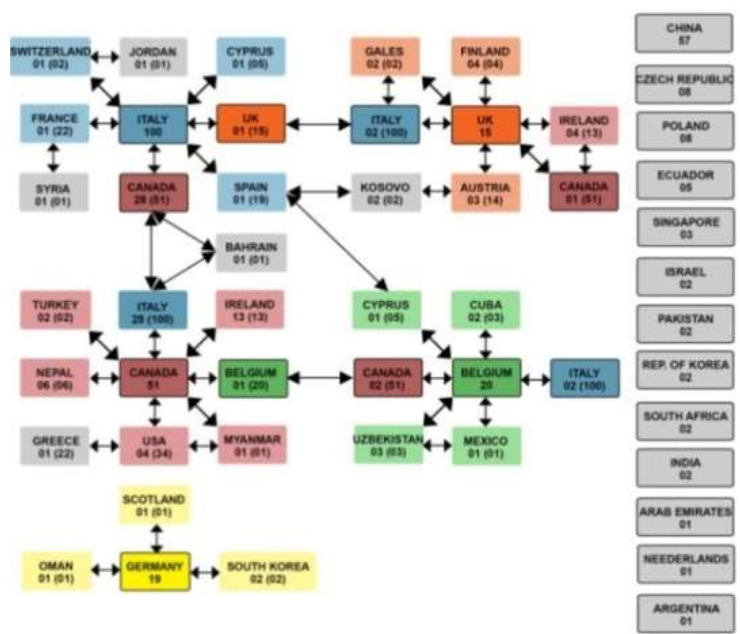

Figure 1: Interaction of foreign researchers by countries

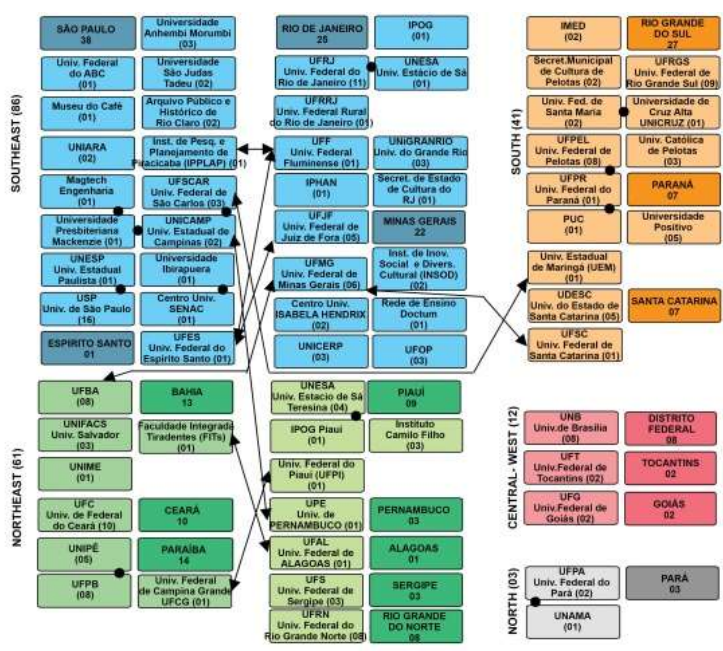

Figure 2: Interaction of Brazilian researchers by regions
In Brazil, we identified that most of the researchers are located in the southeast region (86), which is home to the largest number of educational institutions in the country, followed by researchers from the northeast (61) and the south (41). We observed that there are few researchers from the central-west (12) and north (03) regions. There is a better integration among researchers from the southeast and northeast regions (figure 2).

\section{CONCLUSIONS}

We found a profusion of terms with very similar meaning which makes research difficult to establish more representative terms. Very broad and generic terms serve only to situate the field of research but couldn't clarify the progress of studies on a topic. We plan to systematize techniques, technologies by objectives and conclusions for each thematic group (discovery, scientific process, dissemination) to deepen the research of discovery technologies.

We discovered that Brazilian articles refer to most topics. Principle/criteria group of keywords, although crucial such as Digital workflow, wasn't found. It suggests that further research about these themes is needed in Brazil.

In the group of Discovery technologies, some keywords organized in 3D RECORDING keywords, considered as keys to this kind of research diagram, weren't mentioned by Brazilian research works (Remote sensing, Emergency surveying and Digital workflow). We have a several cultural heritage in risk, and we evaluate that these themes are essential in Brazilian research.

About technologies of Scientific Process, we also didn't observe terms related to Texturing in the group of keywords 3D IMAGING diagram. We know the relevance of this in damage mapping analysis. In the 3D MODELLING terms group, we didn't observe research that refers to Segmentation and Semantic modelling techniques of Point cloud files, nor to NURBS mesh modelling. These are important to ensure that the $3 \mathrm{~d}$ modelling is capable to provide manageable information for further evaluations. In the DOCUMENTATION group we didn't identify the use of the keywords related to Classification, Ontology and Thesauri and information systems that are important to organize the data to useful information in multidisciplinary works.

Concerning to the technologies of Dissemination, the group of keywords related to VISUALIZATION, we can identify that all the themes were found in Brazilian articles. That indicates that there is much interest about these topics in Brazil.

In both undergraduate and postgraduate education at UFRRJ, we discuss about these technologies only theoretically. It is necessary to train educators and students to use digital technologies in all phases of heritage documentation because it is very important to overcome the difficulties of gathering a large set of information, of different sources and formats, to be available to a multidisciplinary team, and guarantee scientific validation and reviewable process of documentation.

We conclude that, even though we find many Brazilian researchers, most of them architects and urbanists, it is imperative to promote new contacts to form a multidisciplinary network to accomplish research with more integration as evidenced in the CIPA Scientific Symposium. 
We will continue this research including more recent articles published by scientific journals, master and doctoral thesis to subsidize the current research, and keep looking at all technologies applied to cultural heritage to ensure greater integration between the multidisciplinary surveys of our postgraduate course.

\section{ACKNOWLEDGEMENTS}

The authors would like to thank Fundação de Amparo à Pesquisa do Estado do Rio de Janeiro - FAPERJ, Edital IC: Bolsa de Iniciação Científica - 2018/1, for the financial support.

\section{REFERENCES}

$3^{\circ}$ Seminário Ibero-americano Arquitetura e Documentação. Anais...Belo Horizonte (MG) UFMG, 2013. ISSN: 1983-7518

$4^{\circ}$ Seminário Ibero-americano Arquitetura e Documentação. Anais...Belo Horizonte (MG) UFMG, 2015.

$5^{\circ}$ Seminário Ibero-americano Arquitetura e Documentação. Anais...Belo Horizonte (MG) UFMG, 2018. ISSN: 2237-5619.

Hermon, S, 2012. Scientific Method, chaine opératoire and Visualization: 3D Modelling as a Research tool in Archaeology. In: Bentkowska-Kafel, Anna, Denard, Hugh, Baker, Drew. Paradata and Transparency in Virtual Heritage. Routledge, pp.13-22, ISBN: 978-0754675839

ICOMOS/ISPRS - International Scientific Committee on Heritage Documentation (CIPA). 26th International CIPA Symposium - Digital Workflows for Heritage Conservation, 28 August-1 September 2017, Ottawa, Canada. Editor(s): J. Hayes, C. Ouimet, M. Santana Quintero, S. Fai, and L. Smith (Volume IV-2/W2, https://doi.org/10.5194/isprs-annals-IV-2-W2-1-2017, Volume XLII-2/W5, 2017 https://doi.org/10.5194/isprs-archivesXLII-2-W5-1-2017, 2017.

II Simpósio Científico 2018 - ICOMOS Brasil, Anais...Belo Horizonte (MG) Universidade Federal de Minas Gerais, vol.1, pp.1-3471., vol.2, pp.3416-7359. ISBN: 978-85-5722-038-6

Letellier, R., Schmid, W., Leblanc, F., 2007. Recording, Documentation, and Information Management for the Conservation of Heritage Places: Guiding Principles. Los Angeles, CA: Getty Conservation Institute, vol 1, 154p. ISBN 978-0-89236-925-6.

Murphy, M., 2007. Parametric Vector Modelling of Laser and Image Surveys of 17th Century Classical Architecture in Dublin. In: D. Arnold, F. Niccolucci, A. Chalmers (Editors). The 8th International Symposium on Virtual Reality, Archaeology and Cultural Heritage. VAST (2007), pp.1-6.

Owen, R., Buhalis, D., Pletinckx, D., 2004. Identifying technologies used in cultural heritage. In: Proceedings of 5th International Symposium on Virtual Reality, Archeology and Cultural Heritage. VAST (2004). incorporating 2nd Eurographics Workshop on Graphics and Cultural Heritage, Conscience-Auditorium, Brussels and Ename Center, Oudenaarde, Belgium, December 7-10, pp. 155-163

Pereira Filho, H. F., 2015. Documentação. In: Rezende, M. B.; Grieco, B., Teixeira, L., Thompson, A. (Gros.). Dicionário
IPHAN de Patrimônio Cultural. 1. ed. Rio de Janeiro, Brasília: IPHAN/DAF/Copedoc. ISBN 978-85-7334-279-6

Quintero, M. S., Blake, B., Eppich, R., 2007. Conservation of Architectural Heritage: The Role of Digital Documentation Tools: The Need for Appropriate Teaching Material. International Journal of Architectural Computing, june, 2007, vol. 5, issue 2, pp. 239-253.

Santana-Quintero M., Addison A.C., 2008. Digital Tools for Heritage Information Management and Protection: The Need of Training. In: Wyeld T.G., Kenderdine S., Docherty M. (eds) Virtual Systems and Multimedia. VSMM 2007. Lecture Notes in Computer Science, vol 4820. Springer, Berlin, Heidelberg, pp. 35-46, https://doi.org/10.1007/978-3-540-78566-8_4

Sperling, D. M., Celani, G., Herrera, P. C., Scheeren, R.., 2015. Fabricação digital na América do Sul: um mapeamento de linhas de ação a partir da arquitetura e urbanismo. In: Proceedings of XIX SIGraDi 2015: Project information for interaction. São Paulo: Blucher Design Proceedings, 2015, pp.119-125, https://doi.org/10.5151/despro-sigradi2015-30212

Vlahakis, V., Karigiannis, J., Tsotros, M., Gounaris, M.; Almeida, L., Stricker, D.; Gleue, T., Christou, I. T., Carlucci, R., Ioannidis, N., 2001. Archeoguide: first results of an augmented reality, mobile computing system in cultural heritage sites. In: VAST' 01 Proceedings of the 2001 Conference on Virtual reality, archeology, and cultural heritage, pp. 131-140, https://doi.org/10.1145/584993.585015

VII Encontro de Tecnologia de Informação e Comunicação na Construção - Edificações, Infraestrutura e Cidade: do BIM ao CIM. Recife (PE), nov. 2015, vol. 2, no. 2, ISSN: 2357-7592 https://doi.org/10.5151/engpro-tic2015-001

XVII SIGraDi 2013: Knowledge-based Design [Blucher Design Proceedings, v.1, n.7]. São Paulo: Blucher Design Proceedings, 2014, pp.1-663, http://dx.doi.org/10.1016/despro-sigradi20130000

XVIII SIGraDi 2014: Design in Freedom [Blucher Design Proceedings, v.1, n.8]. São Paulo: Blucher Design Proceedings, 2014, pp. 1-652, http://dx.doi.org/10.1016/despro-sigradi20140001

XIX SIGraDi 2015: Project information for interaction. [Blucher Design Proceedings, v.2, n.3] São Paulo: Blucher Design Proceedings, 2015, pp.1-840, http://dx.doi.org/10.1016/desprosigradi2015-10288

XX SIGraDi 2016: Crowdthinking. [Blucher Design Proceedings, v.3, n.1] São Paulo: Blucher Design Proceedings, 2016, pp. 1-985, http://dx.doi.org/10.1016/despro-sigradi20160000

XXI SIGraDi 2017: Resilience Design. [Blucher Design Proceedings, v.3, n.12] São Paulo: Blucher Design Proceedings, 2017, pp. 1-663, http://dx.doi.org/10.1016/sigradi2017-101

XXII SIGraDi 2018: Technopolíticas. [Blucher Design Proceedings, v.5, n.1] São Paulo: Blucher Design Proceedings, 2018, pp. 1-1360, http://dx.doi.org/10.1016/sigradi2018-00B 